\title{
Determination of Catechol Using Flow Injection -Electrochemical Detection with Banana Paste Electrode: Application to Adrenaline Determination
}

\author{
Wadala A. Bashir \\ Amer T. Al-Taee \\ Yousra M. Al. Shaker \\ Department of Chemistry \\ College of Science \\ Mosul University \\ Department of Chemistry \\ College of Science \\ Mosul University \\ Department of Environment \\ College of Environment \\ Mosul University
}

(Received 18/11/2009; Accepted 13/7/2010)

\begin{abstract}
This work involves indirect determination of catechol compounds using flow-injection electrochemical detector. The detector based on the three-electrodes system, banana paste [which contained the polyphenyl oxidase (PPO) enzyme] as working electrode, auxiliary electrode Pt wire and silver/silver chloride, saturated potassium chloride Ag/AgCl .sat.KCl as reference electrode. The PPO enzyme in banana paste motivates the oxidation of the two hydroxyl groups in catechol to the o-quinone which is then reduced at $(-0.65) \mathrm{V}$ back to catechol. The reduction current was recorded and it is proportional to concentration of catechol. The technique has been applied to adrenaline hormone.
\end{abstract}

\section{قدير الكالتيكل بلستخدلمطرقة الهن ألجربالي - ألنهس الأكتروكيميائي مع قلب عجينة الموز: الظلبق عل فئلمير الأدرنالين}

\section{الملغص}

يتضنمن البمث طويرطريقة غيرمبلثرة لقديرمركب الكاتيكول بلستخدام التحليل بالهن الجري اني مع ظلم كثثف كهروكميائي ثلاثي الأفلب. يتكون ظالم الكثف من عجينة الموز الحاوية على أنزيم

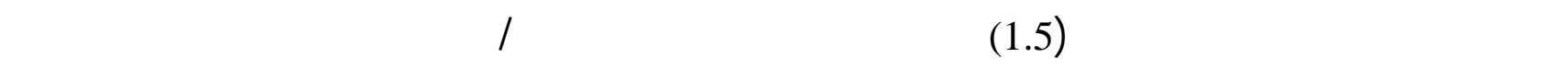

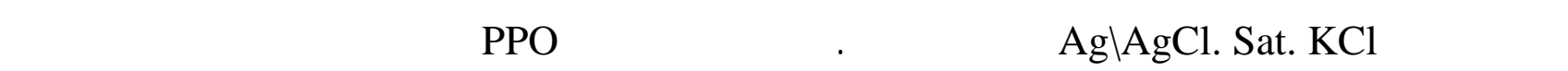

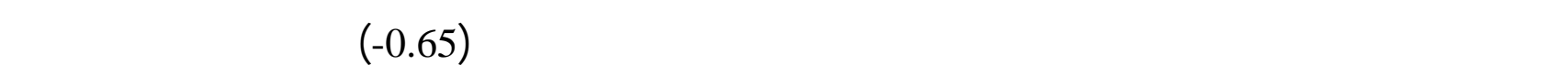
لختزل يتنلسب مع تركيز الكاتيكل . وقم طبيق القنية على هورمون الأدرنالين. 


\section{INTRODUCTION}

The banana detection is considered as one of the simple biological voltammetric detectors which depends on its structure on the tissue of the banana fruit (Dalali et al., 1988)which contains several enzymes with varied rates, especially, the enzymes of peroxides and phenol oxides. The first enzyme helps to turn the banana color into brown, where as the second one works to improve the brown color as a result of the enzymatic browning reactions and producing undesired flavor accompanied with loss of vitamins. The banana electrode was used to estimate dopamine (Eggins, 1990) where polyphenyl oxidase enzymes motivate the catechol oxidation through the surrounding oxygen into o-quinone which could be detected through the reduction on the carbon electrode paste.

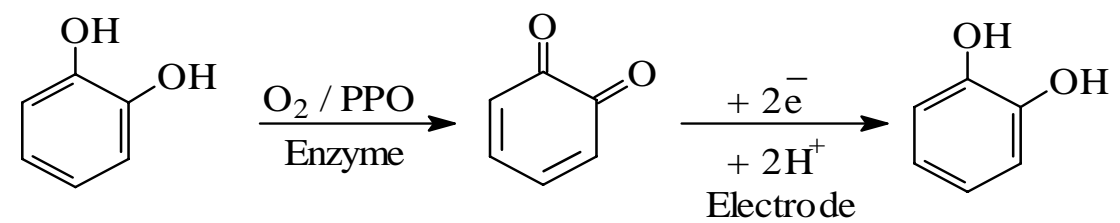

The adrenaline is one of the most important biological catecholamines, which is 1-(3,4dihydroxy phenol)-2-methyl aminoethanol :<smiles>CNCC(O)c1ccc(O)c(O)c1</smiles>

The catechol and its numerous derivatives including uniamine derivatives such as adrenaline, noradrenaline, and dopamine are considered as important biological compounds. Where the uniamine- derivatives are called biogenic amines (Culman et al., 1989), and considered as neurotic transmitters in the brain tissues (Yu et al., 1989 ; Harry et al., 2005). The use of flow-injection system and manual system to measure chemical photic glimmer resulted from adrenaline oxidation (Yamada et al., 1989) through dissolved oxygen in alkaline medium has been accomplished. After injection, the carrier solution containing manganese is mixed up to assist increasing the photic glimmer and the detection range of adrenaline was (10) nano-molar.

In this work, a simple FIA system (Fig. 1) with electrochemical detector (banana paste) has been constructed. The application of this technique was demonstrated by indirect determinations of catechol compounds . 


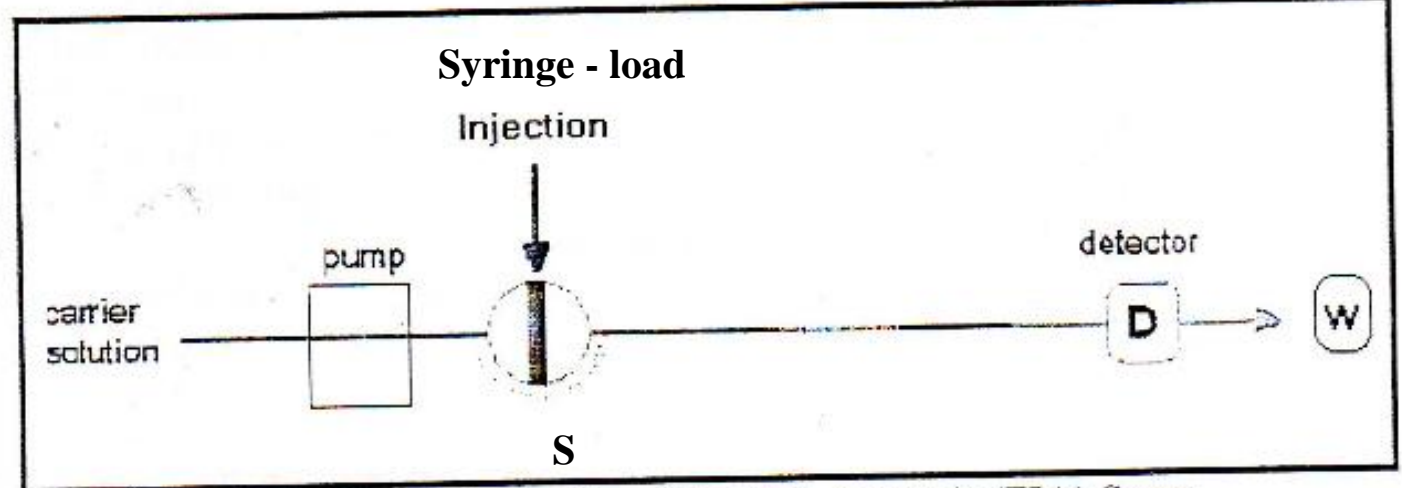

Fig. 1: Show a basic Flow Injection Analysis (FIA) Setup.

\section{THE EXPERIMENTAL}

\section{Apparatus}

The experimental set-up shown in Fig. (1) was constructed as simple flow injection system. The carrier stream (C) is pumped by pump (P) through the electrochemical flow through detector (D) after which the stream is discharge to the waste. The sample is injected at position (S), by means of a disposable plastic-syringe loaded injection into the carrier stream where it is transported as a plug to the detector. The incoming solution impinges on the surface of the working electrode and the resulting signal was recorded using an $\mathrm{x}$ - $\mathrm{t}$ recorder.

The detection system was a home-made single-electrode flow-through cell specially constructed for FIA (Fig. 2). The detection system constructed of two parts, the auxiliary electrode (1.5 mm diameter platinum Pt wire) and the working electrode (composed from 5 mm diameter graphite disc) were placed in one part and a reference electrode sliver/silver chloride, saturated potassium chloride (Ag/ AgCI, Sat. KCI) placed in the second part connected to the cell solution by a vycor ceramic frit. The electrodes assembly were fitted into a teflon body cell as it is a good insulator and easy to machine, and a ( $1 \mathrm{~mm})$ diameter inlet and outlet drilled into the cell body. The two parts of the cell were clamped together with three screws.

The pump is used to propel one or more streams through the detection system via narrow bore (0.3-0.8 mm internal diameter) tubing. In this work the fluid is driven by using peristaltic pump (LKB type). 

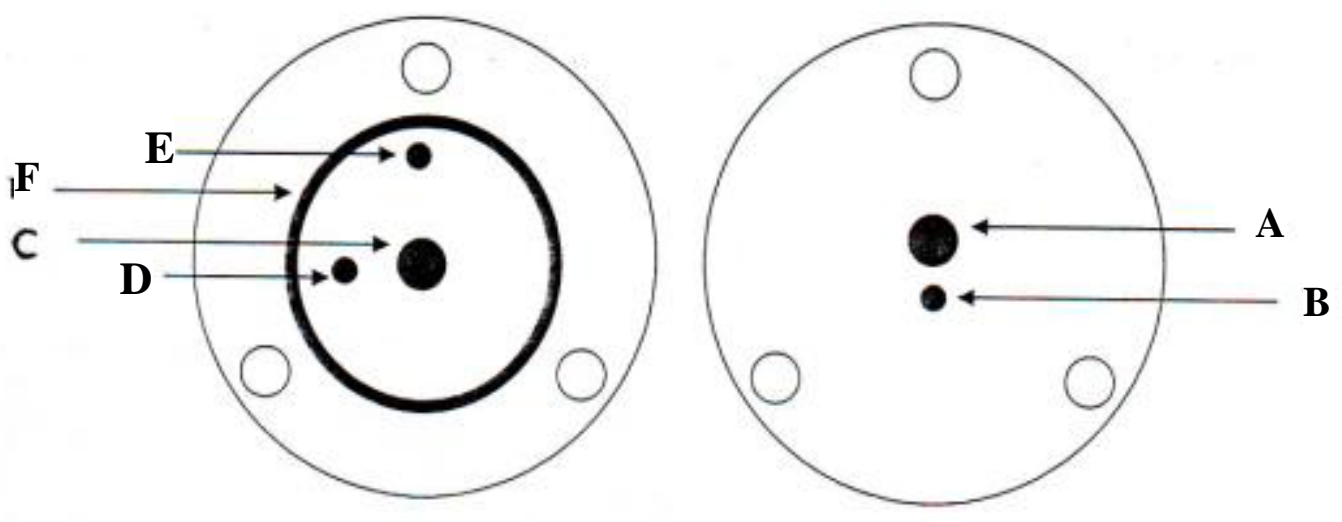

Fig. 2 : Detector Configuration Internal - face view
A: Working electrode ( $5 \mathrm{~mm}$ diameter GC electrode coated with banana tissue paste ) .
D: inlet
B: Auxiliary electrode ( $1.5 \mathrm{~mm}$ diameter Pt wire )
C: Reference electrode ( $\mathrm{Ag} / \mathrm{AgCl}$, Sat . $\mathrm{KCl}$ ) .
E: Outlet
F : o-ring washer

A home-made injection unit was used, the unit is made of Teflon and it involves three holes, one for carrier inlet, second for carrier outlet and third for sample injection.

The tubing material used to connect the FIA units was made of polytetrafluoroethane (PTFE) with a unique diameter of $0.4 \mathrm{~mm}$ inertial diameter .

The flow-system is supplied by a buiret tap (placed between sample injector and detector) to prevent disturbing of the sample zone during the sample injection.

All D.C. voltammetric measurements were performed using a potentiostat type (LB75) and scanning potentiometer type (SMP72) supplied by Gerhard Bank Electronic (Germany) for supplying the required potential, peak current component was recorded using $\mathrm{x}$-t Fisher record all series 5000 .

\section{Preparing of Electrode Surface}

To ensure reproducible results and low background current, Graphite Carbon (GC) electrode was polished using hand polishing with aluminum oxide coated paper (400 P mesh.), followed by fine polishing with aluminum oxide $(0.3,0.075$ and $0.015 \mu \mathrm{m})$ on a polishing cloth for about $10 \mathrm{~min}$.

\section{The preparation of the banana paste}

The paste was prepared by mixing (0.05) g of banana tissue with (0.05) g of graphite powder, then the mixture was grounded using mixing bowel and placed in a hole on the graphite electrode which acts as substrate and conducting material.

\section{CHEMICALS AND SOLUTIONS}

High purity chemicals had been used. 


\section{Catechol solutions (10-500) $\mu \mathrm{g} / \mathrm{ml}$}

(500) $\mu \mathrm{g} / \mathrm{ml}$ of standard catechol solution was prepared by dissolving (0.05) $\mathrm{g}$ of catechol in100 ml distilled water. A serial dilution (10-500) $\mu \mathrm{g} / \mathrm{ml}$ of standard catechol solutions were prepared by appropriate diluting. These catechol solutions were stable for one day.

\section{Phosphate buffer solution}

Phosphate buffer(0.05 M, pH=7) was prepared (Perrin and Dempsey, 1974) by dissolving (6.8) $\mathrm{g}$ of $\mathrm{KH}_{2} \mathrm{PO}_{4}$ in distilled water, and the $\mathrm{pH}$ was adjusted to (6.5) with $\mathrm{NaOH}$ (0.01) $\mathrm{M}$, then the volume was completed to $1 \mathrm{~L}$ by distilled water.

\section{Optimum Conditions}

\section{RESULTS AND DISCUSSION}

In order to optimize the conditions for measurements, the following experiments were carried out.

\section{Effect of pH :}

The effect of the $\mathrm{pH}$ was illustrated using different $\mathrm{pHs}$ of phosphate buffer solution from pH 6 to 8, banana paste electrode (containing $0.05 \mathrm{~g}$ of banana tissue and $0.025 \mathrm{~g}$ of graphite powder), carrier solution was phosphate buffer solution (0.05 M), flow-rate $2 \mathrm{ml} / \mathrm{min}$ and the injected sample was $1 \mathrm{ml}$ of $100 \mu \mathrm{g} / \mathrm{ml}$ catechol solution .

The results obtained are shown in Table (1) and Table (2):

Table 1: Effect of $\mathrm{pH}$ and applied voltage on peak height.

\begin{tabular}{|c|c|c|c|c|c|}
\hline \multirow{2}{*}{$\begin{array}{c}\text { E appl. } \\
(\mathbf{V})\end{array}$} & \multicolumn{5}{|c|}{ Peak height (cm) } \\
\cline { 2 - 6 } & $\mathbf{p H}=\mathbf{6}$ & $\mathbf{p H}=\mathbf{6 . 5}$ & $\mathbf{p H}=\mathbf{7}$ & $\mathbf{p H}=\mathbf{7 . 5}$ & $\mathbf{p H}=\mathbf{8}$ \\
\hline-0.20 & 2.0 & 2.0 & 2.5 & 5.0 & 3.0 \\
\hline-0.25 & 2.0 & 2.5 & 3.0 & 5.0 & 3.7 \\
\hline-0.30 & 4.3 & 3.2 & 4.0 & 5.5 & 3.7 \\
\hline-0.35 & 4.3 & 4.2 & 4.0 & 6.5 & 4.5 \\
\hline-0.40 & 4.5 & 4.2 & 4.0 & 6.0 & 5.8 \\
\hline-0.45 & 4.5 & 4.2 & 4.1 & 6.0 & 5.5 \\
\hline-0.50 & 4.3 & 5.2 & 4.2 & 5.4 & 5.2 \\
\hline-0.55 & 4.3 & 5.2 & 4.4 & 5.4 & 5.2 \\
\hline-0.60 & 4.3 & 5.2 & 5.9 & 5.7 & 4.4 \\
\hline-0.65 & 4.3 & 9.7 & 8.8 & 5.8 & 4.3 \\
\hline-0.70 & 3.2 & 6.0 & 8.6 & 5.5 & 4.3 \\
\hline-0.75 & 2.9 & 5.5 & 6.2 & 5.5 & 3.8 \\
\hline
\end{tabular}

* Average of three measurements at $2 \mathrm{~m} \mathrm{~V}$ sensitivity 
Table 2: Effect of pH and applied voltage on peak height of adrenaline.

\begin{tabular}{|c|c|c|c|c|c|}
\hline \multirow{2}{*}{$\begin{array}{c}\text { E appl. } \\
(\mathbf{V})\end{array}$} & \multicolumn{5}{|c|}{ Peak height (cm)* } \\
\cline { 2 - 6 } & $\mathbf{p H}=\mathbf{6}$ & $\mathbf{p H}=\mathbf{6 . 5}$ & $\mathbf{p H}=\mathbf{7}$ & $\mathbf{p H}=\mathbf{7 . 5}$ & $\mathbf{p H}=\mathbf{8}$ \\
\hline-0.35 & 1.8 & 4.0 & 4.0 & 0.2 & 0.0 \\
\hline-0.40 & 2.0 & 6.0 & 4.6 & 0.8 & 0.4 \\
\hline-0.45 & 2.6 & 8.0 & 4.8 & 1.0 & 0.6 \\
\hline-0.50 & 4.0 & 8.0 & 4.8 & 1.8 & 1.0 \\
\hline-0.55 & 4.0 & 9.8 & 5.0 & 1.8 & 1.2 \\
\hline-0.60 & 4.0 & 9.4 & 5.4 & 2.0 & 1.4 \\
\hline-0.65 & 6.0 & 8.6 & 11.0 & 2.2 & 1.4 \\
\hline-0.70 & 8.0 & 8.6 & 10.0 & 2.2 & 2.6 \\
\hline-0.75 & 10.0 & 8.0 & 9.6 & 2.2 & 2.6 \\
\hline
\end{tabular}

* A verage of three measurements at $10 \mathrm{~m} \mathrm{~V}$ sensitivity.

It had been noticed from Table (1), that with $\mathrm{pH}=6.5$ and reducing potential $(-0.65) \mathrm{V}$ the sample of catechol gave the maximum reduction peak current, and in Table (2) that with $\mathrm{pH}=7$ and reducing potential $(-0.65) \mathrm{V}$, the sample of adrenaline gave the maximum reduction peak current, therefore, this pHs and potential had been used in the subsequent experiments.

\section{Effect of paste components ratio banana tissue amount :}

The effect of banana tissue quantity was studied using different amounts of banana tissue, each amount was mixed with (0.025) g of graphite powder, and placed as a paste in a hole upon the surface of graphite electrode. A phosphate buffer solution $(\mathrm{pH}=6.5)$ was used as a carrier solution and (1) $\mathrm{ml}$ of (100) $\mu \mathrm{g} / \mathrm{ml}$ sample volume was injected into the carrier solution. The reduction peak height was recorded at reduction potential of $(-0.65) \mathrm{V}$ vs.Ag\AgCl. Sat. KCl. The results obtained are shown in Table (3).

Table 3 : Effect of banana quantity on peak heights of catechol and adrenaline.

\begin{tabular}{|c|c|c|}
\hline $\begin{array}{c}\text { Amount of banana } \\
\text { (gm) }\end{array}$ & $\begin{array}{c}\text { Peak height for } \\
\text { catechol } \\
\text { (cm)* }\end{array}$ & $\begin{array}{c}\text { Peak height for } \\
\text { adrenaline } \\
\text { (cm)* }\end{array}$ \\
\hline 0.025 & 15.5 & 0.2 \\
\hline 0.050 & 32.5 & 9.0 \\
\hline 0.075 & 8.0 & 11.0 \\
\hline 0.100 & 8.0 & 2.4 \\
\hline
\end{tabular}

*average of three measurements at $2 \mathrm{~m} \mathrm{~V}$ sensitivity .

It had been noticed that $(0.050) \mathrm{g}$ of banana tissue gave maximum peak current and this quantity was used in the subsequent experiments. 


\section{graphite powder quantity:}

In order to show the effect of graphite powder quantities, different amounts of graphite powder were used (0.025 up to 0.100$) \mathrm{g}$ and mixed with $(0.05) \mathrm{g}$ of banana tissue to construct the banana paste electrode. The reduction current (peak height) was recorded for 1 $\mathrm{ml}$ of $100 \mu \mathrm{g} \backslash \mathrm{ml}$ catechol solution. The results are shown in Table (4).

Table 4 : Effect of graphite powder quantity.

\begin{tabular}{|c|c|c|}
\hline $\begin{array}{c}\text { Amount of graphite } \\
\text { powder (gm) }\end{array}$ & $\begin{array}{c}\text { Peak height for } \\
\text { catechol } \\
\text { (cm)* }\end{array}$ & $\begin{array}{c}\text { Peak height for } \\
\text { adrenaline } \\
\text { (cm)* }\end{array}$ \\
\hline 0.025 & 31.7 & 0.2 \\
\hline 0.050 & 49.3 & 0.6 \\
\hline 0.075 & 50.0 & 11.0 \\
\hline 0.100 & 50.0 & 7.8 \\
\hline
\end{tabular}

*average of three measurements at $2 \mathrm{~m} \mathrm{~V}$ sensitivity .

These results indicate that (0.05) g of graphite powder was the best because it gave a constant reduction peak current and also to minimize the graphite powder consumption. This quantity had been used in the subsequent experiments .

\section{paraffin oil quantity:}

The effect of paraffin oil quantity on the reduction peak current had been studied by mixing different quantities of paraffin oil homogenously with the banana paste. It had been found that any quantity of paraffin oil even if it was very small diminishes the catechol reduction peak, as noticed from Table (5). Therefore, it was excluded in the preparation of paste in all of the subsequent experiments.

Table 5 : Effect of oil quantity.

\begin{tabular}{|c|c|c|c|c|}
\hline Amount of oil (g) & 0.000 & 0.025 & 0.050 & 0.100 \\
\hline $\begin{array}{c}\text { Peak height for } \\
\text { catechol(cm)* }\end{array}$ & 48.5 & 2.5 & 1.0 & 0.3 \\
\hline $\begin{array}{c}\text { Peak height for } \\
\text { adrenaline(cm)* }\end{array}$ & 11.0 & 6.2 & 4.0 & \\
\hline
\end{tabular}

*average of three measurements at $2 \mathrm{mv}$ sensitivity

\section{Effect of flow-rate}

The dependence of signal on flow-rate was examined using phosphate buffer $(\mathrm{pH}=6.5)$ as a carrier, $1 \mathrm{ml}$ of $100 \mu \mathrm{g} / \mathrm{ml}$ catechol injected volume, reduction potential $(-0.65) \mathrm{V}$ and $0.05 \mathrm{~g}$ banana paste contained $0.05 \mathrm{~g}$ graphite powder. Different flow-rates were used from $1.5 \mathrm{ml} / \mathrm{min}$ up to $3.5 \mathrm{ml} / \mathrm{min}$ with increasing interval of $0.5 \mathrm{ml} / \mathrm{min}$. The results obtained are shown in Table (6). 
Table 6: Effect of flow rate on peak height.

\begin{tabular}{|c|c|c|c|}
\hline $\begin{array}{c}\text { Flow rate } \\
\text { (ml/min) }\end{array}$ & $\begin{array}{c}\text { Time of } \\
\text { response } \\
\text { (sec) }\end{array}$ & $\begin{array}{c}\text { Peak height for } \\
\text { catechol } \\
\text { (cm)* }\end{array}$ & $\begin{array}{c}\text { Peak height for } \\
\text { Adrenaline } \\
\text { (cm)* }\end{array}$ \\
\hline 1.5 & 15.0 & 8.0 & 6.4 \\
\hline 2.0 & 12.0 & 10.0 & 7.8 \\
\hline 2.5 & 10.0 & 22.0 & 9.4 \\
\hline 3.0 & 6.0 & 48.0 & 11.0 \\
\hline 3.5 & 6.0 & 48.0 & 11.0 \\
\hline
\end{tabular}

$*$ average of three measurements at $2 \mathrm{~m} \mathrm{~V}$ sensitivity.

As can be seen, the peak height increases with increasing the flow rate up to $3 \mathrm{ml} / \mathrm{min}$ and then became constant. The flow rate (3-3.5) $\mathrm{ml} / \mathrm{min}$ represents the optimum flow rate for measurement. This is because a small change in setting of the flow rate does not make any change in peak current, this will reduce the measurement error and it gives the higher peak current.

\section{Calibration curve of catechol}

The calibration curve was constructed by injecting a serial dilution of standard catechol solution into a phosphate buffer carrier solution under the optimum conditions, (Table 7), the resulting signals were recorded on an $x$-t recorder. The results obtained are summarized in Table (7).

Table 7 : The optimal conditions for determination of catechol.

\begin{tabular}{|c|c|}
\hline Variable & Optimum value \\
\hline Type of paste electrode & $\begin{array}{c}0.050 \mathrm{~g} \text { of banana tissue }+0.050 \mathrm{~g} \\
\text { graphite powder }\end{array}$ \\
\hline $\mathrm{pH}$ & 6.5 \\
\hline $\mathrm{E}$ applied & $-0.65 \mathrm{volt}$ \\
\hline Injected volume & $1.0 \mathrm{ml}$ \\
\hline Flow rate & $3.0 \mathrm{ml} / \mathrm{min}$ \\
\hline
\end{tabular}

Table 8: Effect of concentrations of catechol.

\begin{tabular}{|c|c|c|c|c|c|c|c|c|c|c|c|c|c|c|}
\hline $\begin{array}{c}\text { Conc. of } \\
\text { catechol } \\
\text { (pg/ml) }\end{array}$ & 10 & 20 & 30 & 40 & 50 & 60 & 70 & 80 & 90 & $\begin{array}{c}10 \\
0\end{array}$ & $\begin{array}{c}20 \\
0\end{array}$ & $\begin{array}{c}30 \\
0\end{array}$ & $\begin{array}{c}40 \\
0\end{array}$ & $\begin{array}{c}50 \\
0\end{array}$ \\
\hline $\begin{array}{c}\text { Peak height } \\
\text { (cm)* }\end{array}$ & 10 & 18 & 21 & 24 & 29 & 34 & 36 & 40 & 42 & 47 & 66 & 84 & $\begin{array}{c}10 \\
0\end{array}$ & $\begin{array}{c}11 \\
8\end{array}$ \\
\hline
\end{tabular}

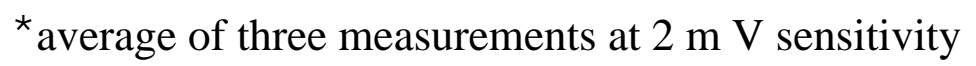

The plot of peak current recorded as peak heights in cm vs. concentration is shown in Fig. (3 and 4), two calibration curves were observed one at low concentration (10-100) $\mu \mathrm{g} / \mathrm{ml}$ 
Determination of Catechol Using Flow....

with $r^{2}$ value (0.9866) and second at high concentrations (100-500) $\mu \mathrm{g} / \mathrm{ml}$ with $\mathrm{r}^{2}$ value (0.9994) respectively.

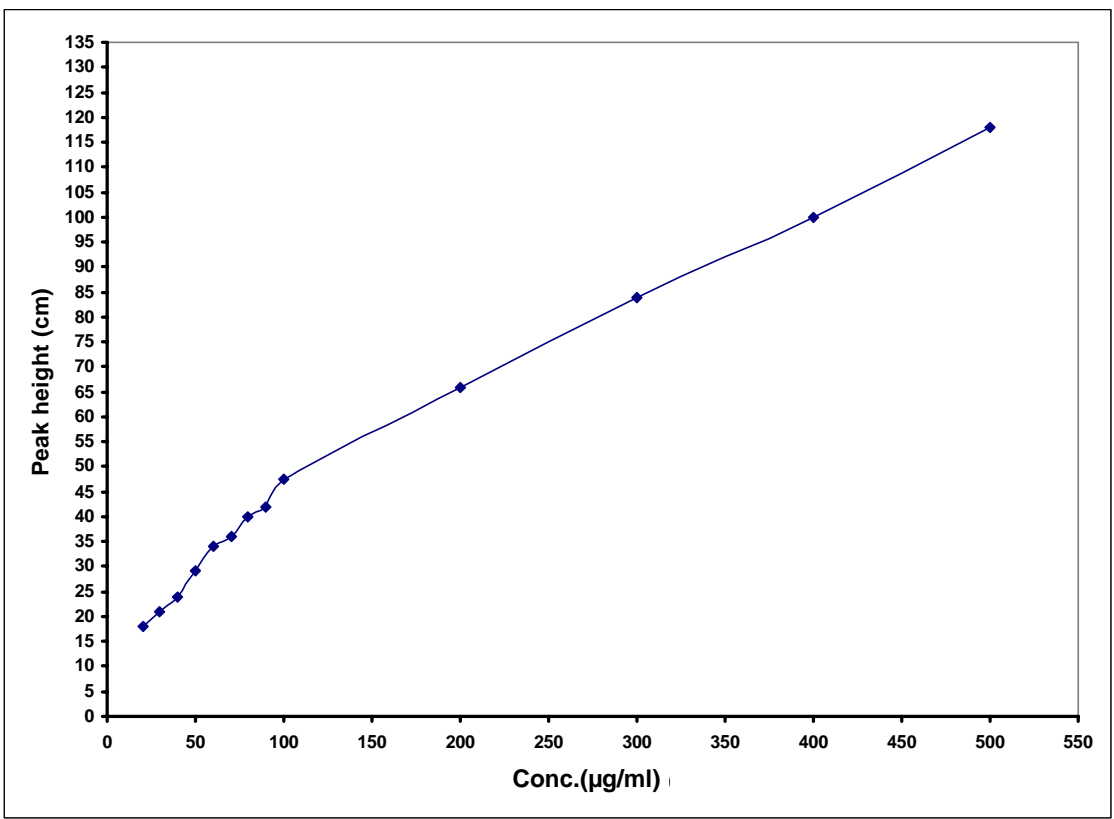

Fig. 3 : The calibration curve of Catechol at low and high concentrations.

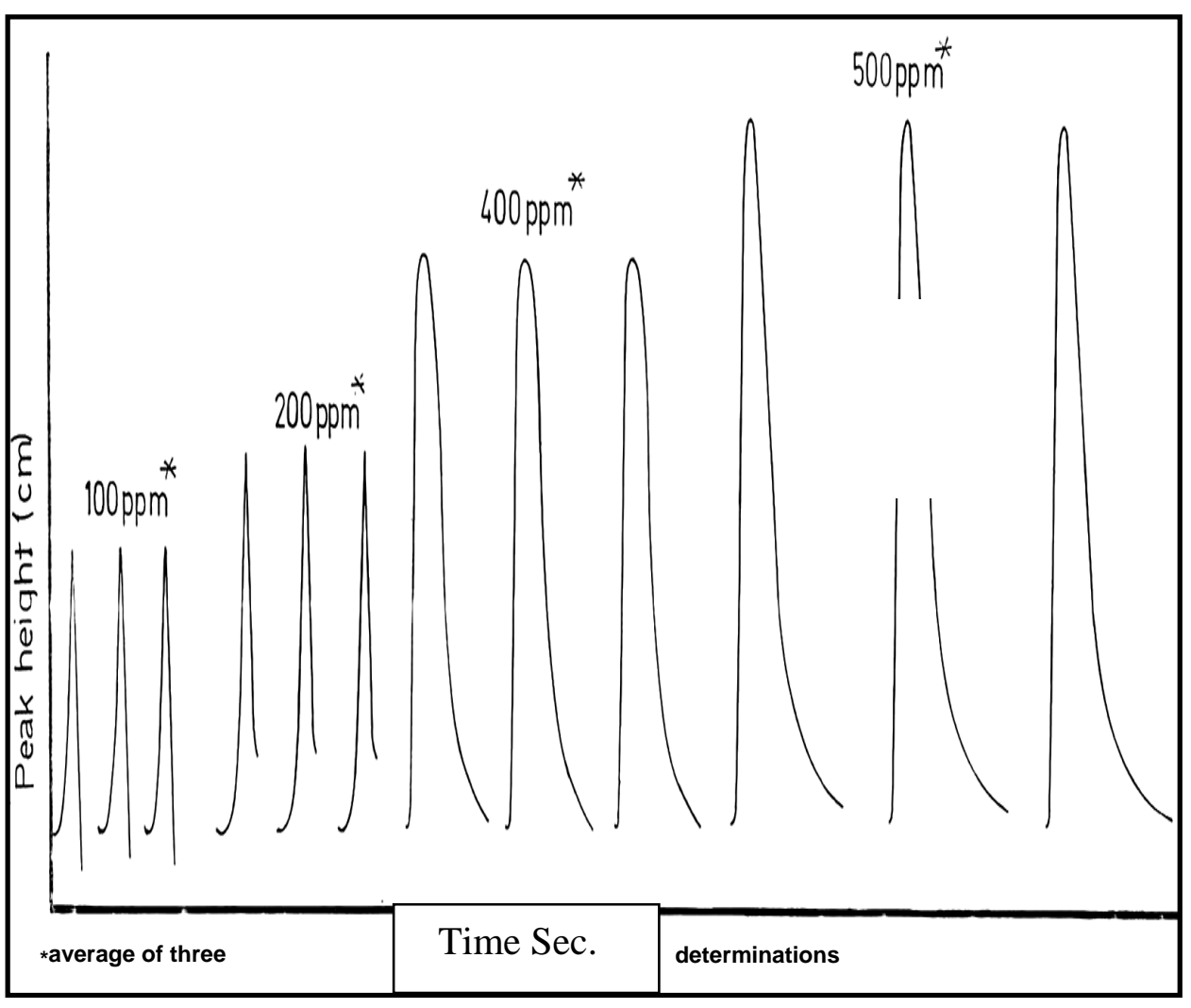

Fig. 4 : Effect of different concentrations of catechol on the peak hight. 


\section{Accuracy and precision}

The accuracy and precision of the standard calibration curve represented by relative standard deviation and relative error were examined through triplicate injecting of different concentrations of catechol solution and the resulting peak heights were recorded under the previous optimum conditions. The results obtained compared with standard calibration curve and summarized in Table (9).

Table 9 : The accuracy and precision.

\begin{tabular}{|c|c|c|c|}
\hline $\begin{array}{c}\text { Concentration } \\
(\mathbf{\mu g} / \mathbf{m l})\end{array}$ & $\begin{array}{c}\text { Peak height } \\
(\mathbf{c m})^{*}\end{array}$ & R.S.D. & $\begin{array}{c}\text { Relative error } \\
\mathbf{( \% )}\end{array}$ \\
\hline 20 & 16.5 & \pm 12.84 & -8.3 \\
\hline 40 & 22.5 & \pm 8.83 & -6.25 \\
\hline 60 & 36.5 & \pm 10.38 & +7.35 \\
\hline 90 & 41.0 & \pm 3.35 & -2.38 \\
\hline
\end{tabular}

* average of three measurements at $2 \mathrm{mv}$ sensitivity.

\section{Calibration curve of adrenaline}

The calibration curve was constructed by injecting a serial dilutions of standard adrenaline into a carrier of phosphate buffer solution . The results are shown in Table (10).

Table 10: Effect of different concentrations of adrenaline on peak heights.

\begin{tabular}{|c|c|}
\hline $\begin{array}{c}\text { Concentration of } \\
\text { adrenaline }(\mathbf{\mu g} / \mathbf{m l})\end{array}$ & $\begin{array}{c}\text { Peak height } \\
\mathbf{( c m})^{*}\end{array}$ \\
\hline 10 & 2.8 \\
\hline 20 & 3.4 \\
\hline 30 & 4.4 \\
\hline 40 & 5.4 \\
\hline 50 & 6.6 \\
\hline 60 & 7.4 \\
\hline 70 & 8.6 \\
\hline 80 & 9.4 \\
\hline 90 & 10.0 \\
\hline 100 & 10.8 \\
\hline 200 & 20.0 \\
\hline 300 & 28.0 \\
\hline 400 & 36.0 \\
\hline 500 & 40.0 \\
\hline
\end{tabular}

The plot of peak current represented by peak height vs. concentrations givesd straight line within the concentrations range of $(10-500) \mu \mathrm{g} / \mathrm{ml}$ with $\mathrm{r}^{2}$ value (0.9926). 


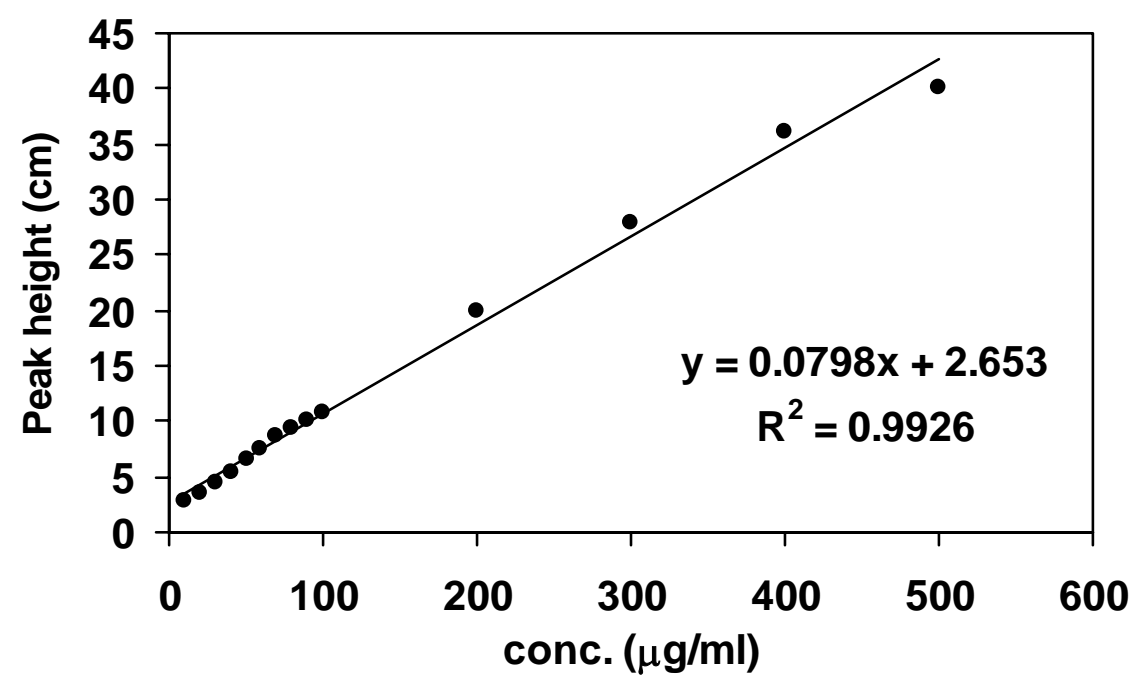

Fig. 5 : The calibration curve of adrenaline.

\section{CONCLUSION}

Catechols compounds can be determined by flow injection electrochemical detector using banana paste electrode. The PPO enzyme in the banana paste catalyze the oxidation of the two hydroxyl groups to carbonyl groups. The formed carbonyl groups are then electrochemically reduced back to catechol and gave a reduction current which is proportional to the concentration of catechol. The method was rapid, easy and accurate.

\section{REFERENCES}

Dalali, B.K. ; Al-Rekabi, K. H. (1988). "Foods Chemistry". , Baghdad University Press.

Eggins, B.R. (1990). "Biosensors: An Introduction”. John Wiley and Sons, Chichester. pp.1-9.

British pharmacopoeia , 2002. CD-ROM , London.

Glockl, I.; Blaschlke, G. ; Veit, M. (2001). Validated method for direct determination of hydroquinone glucuronide and sulfate in human urine after oral intake of bearberry leaf extract by capillary zone electrophoresis. J. Chromatog. B: biomed. Sci. Appli., 761(2), 261-266.

Kalnovicova, J. C. ; Balaz, V. (1989). "Estimation of biogenic amines in rat brain by the HPLC-ED [electrochemical detection] method. Biologia, 44(4), 359-367; Anal. Abst., (1990), 52(12), 12D162

Yamada, K.; Suzuki, M. ; Hobo, T. (1989). Dimethyldioctadecyl-ammonium chloride bilayer membrane vesicle-enhanced and manganese (II)-catalysed chemiluminescence for determination of adrenaline by a flow-injection. Anal. Lett., 22(11-12), 2445-2461; Anal. Abst., 52(6), 6E30.

Harry, N. ; Mark, J. (2005). Development of sensors based on conducting organic polymer electrodes. www.googel. 29/7/2005.

Ruzicka, J. ; Ivaska, A. (1997). Bioligand interaction assay by flow injection absorptimetry, Anal. Chemi., 69, pp. 5024-5030.

Yu, Z. ; Yang, Y. (1989). HPLC determination of monoamine neurotransmitters in brain tissues of rat. Gongye Weisheng Yu Zhiyebing, 15(2), 110-113; Anal. Abst., 52(10), 9D158. 